\title{
Ecosystem-Based Management to Support Conservation and Restoration Efforts in the Danube Basin
}

\author{
Andrea Funk, Timothy G. O'Higgins, Florian Borgwardt, Daniel Trauner, \\ and Thomas Hein
}

\begin{abstract}
Biodiversity and environmental integrity of river systems in the Danube catchment is threatened by multiple human alterations such as channelization, fragmentation or the disconnection of floodplains. Multiple human activities, including the construction of hydropower plants, expansion of agricultural use, and largescale river regulation measures related to navigation and flood protection, are resulting in an ongoing loss of habitat, biodiversity and ecosystem service provision. Conservation and restoration of the systems biodiversity and ecosystem service provisioning is a key task for management but is challenging because the diversity of human activities and policy targets, scarcity of data compared to the complexity of the systems, heterogeneity of environmental problems and strong differences in socio-economic conditions along the Danube River hampers coordinated planning at the scale of the whole river basin and along the whole river from source to mouth. We evaluated three different implementations of an Ecosystem-Based Management (EBM) approach, which aims to support management efforts. This was done following the principles for EBM related to the resilience of ecosystems, the consideration of ecological and socio-economic concerns, the inclusion of multi-disciplinary knowledge and data addressing the ecosystem scale independent of administrative or political boundaries. This approach has been developed in the $\mathrm{H} 2020$ project AQUACROSS.
\end{abstract}

\author{
A. Funk $(\bowtie) \cdot$ D. Trauner $\cdot$ T. Hein \\ University of Natural Resources \& Life Sciences, Vienna, Austria \\ WasserCluster Lunz, Lunz am See, Austria \\ e-mail: andrea.funk@boku.ac.at \\ T. G. O'Higgins \\ University College Cork, National University of Ireland, Cork, Ireland \\ F. Borgwardt \\ University of Natural Resources \& Life Sciences, Vienna, Austria
}

(C) The Author(s) 2020 


\section{Lessons Learned}

- Coupled modelling frameworks are a useful tool for modelling biodiversity restoration measures

- Multiple policy targets can be harmonized with this approach

\section{Needs to Advance EBM}

- Continued international cooperation informed by costed measures

\section{Introduction}

The core principle of Ecosystem-Based Management (EBM) is to concurrently consider biodiversity and human society as integral parts of the ecosystem and manage the socio-ecological system as a whole (Domisch et al. 2019; Langhans et al. 2019). Delacámara et al. (2020) review the many 'flavours' of EBM to identify six characteristics or principles, which set EBM apart from other types of management:

1. It considers ecological integrity, biodiversity, resilience and ecosystem services

2. It is carried out at appropriate spatial scales

3. It develops and uses multi-disciplinary knowledge

4. It builds on social-ecological interactions, stakeholder participation and transparency

5. It supports policy coordination

6. It incorporates adaptive management.

While these EBM principles are not proscriptive, i.e. any particular EBM activity is not required to have all these characteristics, they may offer useful criteria by which EBM activities may be practically assessed.

The Danube River Basin (DRB) is the most international river basin in the world shared by more than 80 million people across 19 countries (Fig. 1). The Danube River connects with 27 large and over 300 small tributaries on its way from the Black Forest to the Black Sea, covering a catchment size of approx. $800,000 \mathrm{~km}^{2}$.

As a result, a huge variety of human activities and related pressures affect this area and a number of major environmental issues threaten the ecosystems of the Danube. As Europe's second longest river, the Danube has long been a major transport corridor. Today, it connects Europe's largest port of Rotterdam with the Black Sea via the Rhine-Main-Danube canal. Physical modifications of the river morphology to accommodate transport and power production have altered flow regimes with serious consequences for ecosystems including the disconnection of the river from its natural flood plains. Agricultural activities along the Danube have resulted in pollution by nutrients and pesticides. The combined effects of these and other pressures have resulted in overall degradation of the freshwater ecosystems and severe declines in iconic species such as different sturgeon species. The 


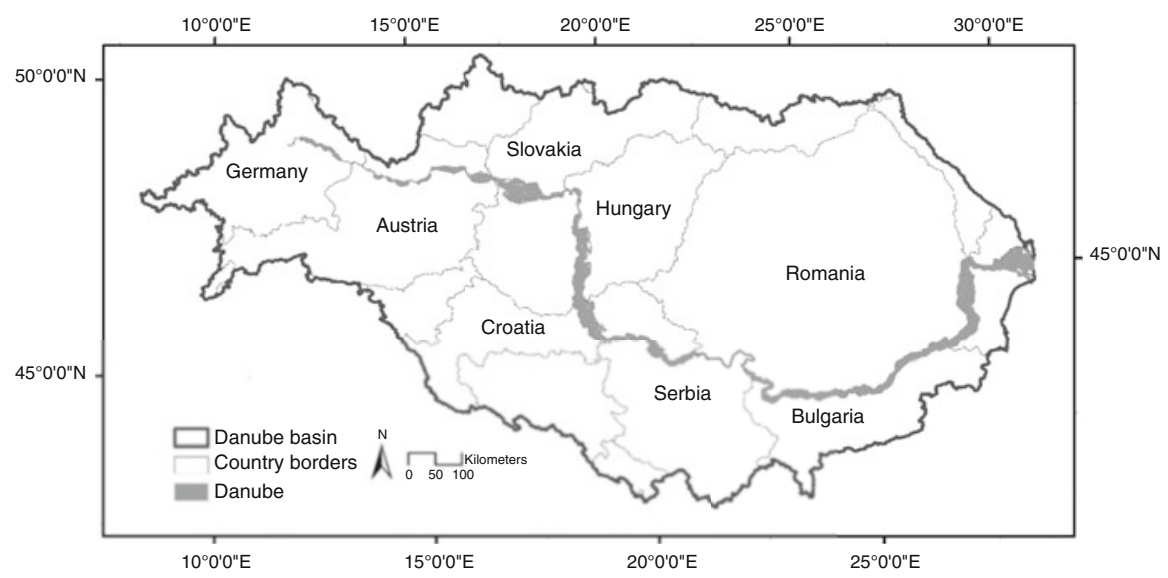

Fig. 1 The Danube River Basin and the corridor of the Danube river

International Commission for the Protection of the Danube River (ICPDR) provides a formal international mechanism for environmental management collaboration across the Danube Basin (detailed information on the many environmental issues can be found on their website (https://www.icpdr.org/main/).

Despite conservation efforts, ongoing and partially conflicting demands within and among the different neighboring countries, inconsistencies in legislation, high administrative and socioeconomic complexity as well as partially lack of on-site expert knowledge all hamper sustainable management (Hein et al. 2016, 2018; Habersack et al. 2016).

There are two major challenges for the management of the DRB. The multicultural setting makes transboundary issues extremely difficult and challenging. For example, the basin lies in the historical political border between capitalist and communist countries, which greatly influences the socio-economic situations, social behaviors, technical developments, as well as water uses and protections between the two former systems (Sommerwerk et al. 2010) and resulting in varying priorities towards, and capacities for, environmental protection (O'Higgins et al. 2014). In the DRB, this historical background is well reflected in the structural differences between the Upper Danube (capitalist countries) where hydro-morphological alteration is high but pollution is low, while in the Lower Danube (former communist countries) pollution is still a highly relevant issue but level of impact due to river engineering works is still relatively low (Sommerwerk et al. 2010). This phenomenon is also reflected in the ranking of stressors along the Danube River. Hein et al. (2018) found that for the Upper Danube hydro-morphological alterations due to hydropower generation, navigation, and flood protection has the highest importance followed by forestry, disturbance due to recreational activities, recreational fisheries and last by pollution, whereas the Lower Danube is mostly impacted by land use including forestry, agriculture and urbanization having an direct as well as an pollution effect on the system and last by hydro-morphological alterations of the river. 
Table 1 Policies directives and initiatives with synergistic and antagonistic effects on conservation objectives in the DRB

\begin{tabular}{|c|c|c|}
\hline $\begin{array}{l}\text { Instrument } \\
\text { type }\end{array}$ & Name & Targets and goals \\
\hline \multirow[t]{2}{*}{ Policy } & EU Biodiversity Strategy & $\begin{array}{l}\text { Full implementation of the Birds and Habitats } \\
\text { Directives }\end{array}$ \\
\hline & $\begin{array}{l}\text { EU Strategy for the Dan- } \\
\text { ube Region }\end{array}$ & $\begin{array}{l}\text { e.g. Sturgeon } 2020 \text { program for the protection and } \\
\text { rehabilitation of sturgeon }\end{array}$ \\
\hline \multirow[t]{5}{*}{$\begin{array}{l}\text { Legally bind- } \\
\text { ing directives }\end{array}$} & $\begin{array}{l}\text { Water Framework Direc- } \\
\text { tive (2000/60/EC; WFD) }\end{array}$ & $\begin{array}{l}\text { Good Ecological Status-through implementation } \\
\text { of the Danube River Basin Management Plan }\end{array}$ \\
\hline & Flood Risk Directive & Danube Flood Risk Management plan \\
\hline & $\begin{array}{l}\text { Birds Directive (2009/ } \\
\text { 147/EC) }\end{array}$ & Favorable conservation status (for selected species) \\
\hline & $\begin{array}{l}\text { Habitats Directive }(92 / 43 / \\
\text { EEC) }\end{array}$ & Favorable conservation status (for selected habitats) \\
\hline & $\begin{array}{l}\text { Renewable Energy } \\
\text { Directive }\end{array}$ & $\begin{array}{l}\text { Total of } 20 \% \text { of EU energy needs to be supplied by } \\
\text { renewable sources (including hydro power). }\end{array}$ \\
\hline Initiative & $\begin{array}{l}\text { Trans-European Transport } \\
\text { Network }\end{array}$ & $\begin{array}{l}\text { Good navigability for important waterways, } \\
\text { including the removal of obstacles }\end{array}$ \\
\hline
\end{tabular}

The second major challenge in DRB management is to establish synergies among multiple competing interests and policy targets including e.g. navigation, hydropower production, flood protection and nature conservation (Sommerwerk et al. 2010). Human stressors interact with the management goals of the Water Framework Directive (EC 2000) or Nature Directives (EC 1992) and the Biodiversity Strategy to 2020 (EC 2011), resulting in potential synergies and conflicts between the various management goals. The implementation of sectoral policies on hydropower (renewable energy), navigation, and flood protection may show significant synergies and antagonisms, and the interaction of their implementation significantly influences the actual type and extent of pressures on rivers. Table 1 lists some of the interrelated directives, policies and initiatives with specific relevance to the management of the Danube River and its associated ecosystems.

For example, the Flood Risk Directive (EC 2007) aims at reducing risk of flooding along water courses including natural water retention measures (e.g. dyke relocation to provide more space for rivers). Floodplains are therefore a key element of the EU Green Infrastructure Strategy (ICPDR 2016). Like-wise navigation projects might either have a synergistic effect on nature protection goals in already significantly altered river sections (if ecological restoration is supported within the project), or an antagonistic effect in intact river sections where every intervention may create a conflict with nature protection goals (DANUBEPARKS 2011). With a multitude of interacting environmental and other directives, management targets can have synergistic as well as antagonistic effects, which vary from place to place. Moreover, these interactions are complex and not sufficiently understood.

In this context, modern management concepts can neither exclusively focus on the mitigation of single pressures or stressors nor can they limit their measures to 
single ecosystem components, species groups or other single targets. In contrast, they have to consider complex interactions and feedback loops between the ecosystems and the society. Thus, for the future, explicit and well-defined ecosystem-based targets need to be formulated, and adequate measures need to be defined to achieve more resilient ecosystems, guarantee the provision of a broad range of ecosystem services, and increase the resilience against emerging stressors like climate change or invasive species (Hein et al. 2018). Given the need for holistic catchment scale management approaches (Hein et al. 2018; Seliger et al. 2016), EBM offers the potential to incorporate multiple objectives related to biodiversity, ecosystem services and socio-economic benefits into a single, harmonized management approach for the DRB. The Danube River, as one of the largest river-floodplain systems in Europe, is a highly complex, threatened and challenging socio-ecological system, and therefore an ideal system to test and apply an EBM approach. To this end, within the frame of the AQUACROSS research project a number of tools and techniques were combined and tested for application in the Danube catchment. In this paper we describe and discuss three different approaches and provide a qualitative assessment of how these methods relate to the EBM principles identified above.

\section{The Studies}

Other authors in this volume (Fulford et al. 2020; Lewis et al. 2020) have addressed the challenges of model design and selection and the potential for combining models to address particular situations. We evaluate three different quantitative and qualitative approaches that have been applied at the Danube catchment scale to describe and model the socio-ecological system. A linkage framework approach (Borgwardt et al. 2019; Teixeira et al. 2019; Robinson \& Culhane 2020) was used to assess the relationships between different activities within the catchment and their relations to biodiversity and ecosystem services. The potential of EBM was also tested within two quantitative studies following an EBM planning framework based on a generic model-coupling approach proposed by Langhans et al. (2019). The workflow consists of three elements a spatial (model-based) representation of (1) biodiversity, (2) ecosystem services (ESS), and (3) a combined spatial prioritization of biodiversity and ESS supply and demand.

Finally, Domisch et al. (2019) combined the ARIES (Artificial Intelligence for Ecosystem Services) modelling framework (Villa et al. 2014) with the application of MARXAN (Ball et al. 2009) to identify a range of spatially explicit management zones and options. Funk et al. (2019) combined Bayesian Belief Network Modelling with the ARIES model to identify river reaches maintaining multiple ecological functions and support multiple services to prioritize individual areas for conservation incorporating a range multiple restoration criteria. 


\subsection{Linkage Frameworks}

A Linkage Framework (LF) for the Danube Basin (Fig. 2) identified 53 specific human activities (or Drivers) occurring in the catchment (Borgwardt et al. 2019). Furthermore, 35 different pressures in five different categories (biological, chemical, physical, energy, and exogenous/unmanaged) were identified, as well as 33 ecosystem components ( 27 habitats and 6 biotic groups). These components were linked to 27 ecosystem services (ESS) and abiotic outputs. Over 23,000 impact chains relating drivers-pressures and ecosystem components were identified and categorized. To investigate the impact chains, their connectance was calculated and linkages were also weighted in terms of the extent, frequency, dispersal, severity and persistence of interactions to increase their explanatory power. Analysis of the impact risk of

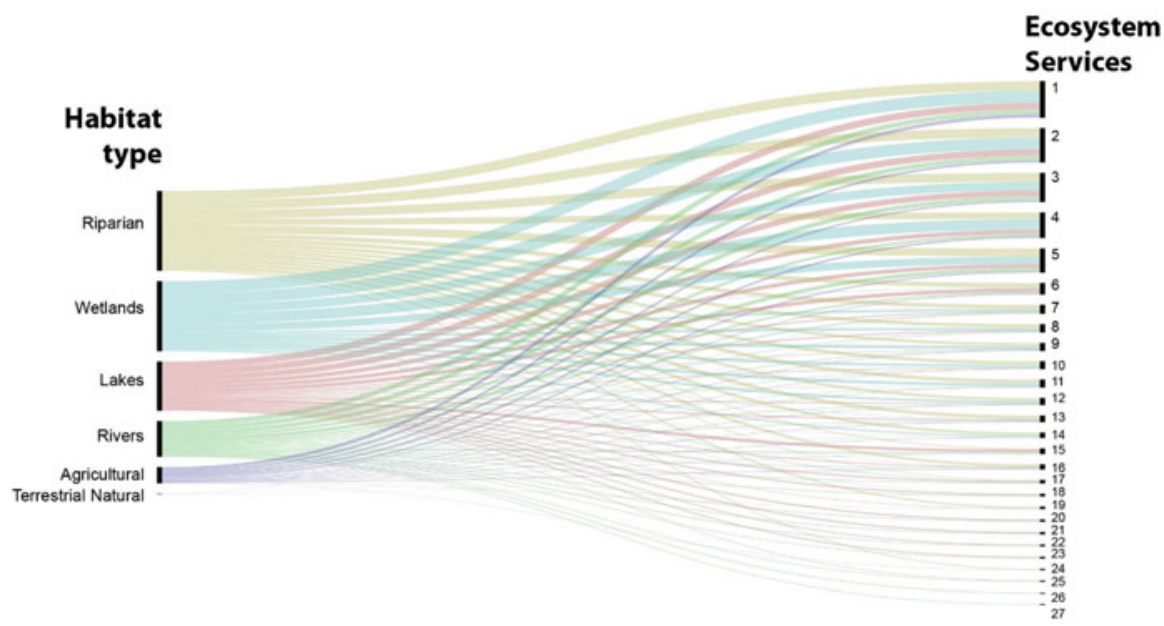

1. Scientific; education; heritage; aesthetic; entertainment

2. Existence; bequest

3. In-situ recreational activities involving biota

4. Lifecycle maintenance, habitat and gene pool protection

5. Mediation of waste by biota

6. Symbolic; sacred and/or religious

7. Atmospheric composition and climate regulation

8. Mediation of waste by ecosystems

9. Water conditions

10. Soil formation and composition

11. Mass flows (erosion protection)

12. liquid flows (flood protection)

13. Maintenance of physical and chemical abiotic condition by natural chemical and physical processes (e.g climager regulation)

\author{
14. Mediation of air flows by biota (shelter) \\ 15. Provision of biomass for nutrition \\ 16. Mediation of waste by physcial and chemical processes \\ 17. In-situ recreational activities involving landscapes \\ 18. Provision of biomass \\ 19. Pest and disease control \\ 20. Provision of drinking water water \\ 21. Provision water for other purposes \\ 22. Mediation of flows by natural abiotic structures \\ 23. Spiritual and emblematic value of landscapes \\ 24. Biomass based energy sources \\ 25. Existence and beqquest values for landsacpes \\ and phyical settings \\ 26. Abiotic reneable energy (eg. hydroelectricity) \\ 27. Abstraction of rocks and minerals
}

Fig. 2 Flow diagram of the linkage framework depicting impact chains from habitat type to ecosystem services 
pressures on ecosystem components revealed that physical change poses the highest threat to freshwater systems and to fish. Physical pressures are highly linked to environmental engineering and hydropower but also to the direct effects of land claim or land conversion activities (Borgwardt et al. 2019). Further along the impact chain, the ecosystem components within the Danube catchment were identified to have the capacity to supply 27 ESS (regulating and maintenance, provisioning, and cultural services and abiotic). Floodplains with their riparian forests and wetlands were the highest connected realms providing the greatest variety of ecosystem services.

\subsection{Coupled Models: ARIES and MARXAN}

Domisch et al. 2019 tested the EBM approach within the whole DRB by combining species distribution modelling for 85 fish species as a surrogate for biodiversity with four estimated ESS layers (carbon storage, flood regulation, recreation and water use) using the modeling platform ARIES. In a final step, multiple management zones were defined using the spatial prioritization tool Marxan with Zones to derive different spatially explicit management options for the whole region. In order to explore the transboundary challenges of the Danube catchment management the costs of establishing management zones were compared across nations using purchasing power parity (PPP) adjusted gross domestic product (GDP) per capita and the relative share of each country's area of the DRB. This approach therefore accounted for countries having limited financial resources (i.e. a proxy for social equity in the EBM approach) and less land area in the DRB as those might face additional challenges in financing EBM. Finally, they compared the spatial plan derived from an assumption where each country contributes equally to the EBM to one where the PPP-adjusted GDP and the percent area of each country in the basin were used as additional costs. The two analyses led to clear differences in the spatial configuration of management zones, in the GDP and percent area approach more conservation and critical management zones (with medium level of ecosystem service use) were allocated to the (wealthier) upper Danube region.

Domisch et al. 2019 used Marxan with Zones, to minimize the overall costs of a zoning plan, while ensuring that the predefined feature targets were met. Therefore four zones were characterized by different objectives and constraints (1) a "focal conservation zone", (2) a "critical management zone"-a buffer zone-, (3) a "catchment management zone" allowing for higher levels of ESS use potentially less compatible with protecting biodiversity (i.e., recreation), and (iv) a "production" zone with high use for ecosystem services (i.e., water use). 


\subsection{Coupled Models: Bayesian Belief Networks and ARIES}

Funk et al. (2019) employed a coupled modelling approach at the scale of the Danube River to prioritize river-floodplain stretches of the navigable Danube for restoration and conservation, focusing on the river and its adjacent floodplains and riparian area (rather than the entire catchment). Bayesian Belief Networks (BBN: graphical models which represent the probabilistic relationships between different components of a system) were used to integrate different sources of information on Drivers and Pressures and their effects on environmental State (Elliott \& O'Higgins, 2020). Open access GIS Datasets for Drivers and pressures included: land use data, potential riparian zone transport and navigation, and hydro-morphological pressures. This information was then used to inform weighting of the relationships within the BBNs.

Based on spatial information on conservation status based on the Habitats Directive reporting, BBNs were generated to spatially model likely species distribution in relation to the combinations of drivers and pressures for each of eleven indicator species representative of different habitat types (Table 2). The predictive power of these BBN models was tested statistically (using the R statistical computing package (see Funk et al for full details).

Table 2 Biodiversity indicators used by Funk et al. (2019)

\begin{tabular}{|c|c|c|c|}
\hline Class & Species & Common name & Indicator \\
\hline \multirow[t]{6}{*}{ Fish } & $\begin{array}{l}\text { Gymnocephalus } \\
\text { baloni }\end{array}$ & Danube ruffe & Fast moving waters \\
\hline & $\begin{array}{l}\text { Gymnocephalus } \\
\text { schraetser }\end{array}$ & striped ruffe & Main stem larger river \\
\hline & Rhodeus amarus & $\begin{array}{l}\text { European } \\
\text { bitterling }\end{array}$ & Stagnant water-connectivity \\
\hline & Misgurnus fossilis & $\begin{array}{l}\text { European } \\
\text { weatherfish }\end{array}$ & Stagnant waters \\
\hline & Zingel zingel & common zingel & $\begin{array}{l}\text { Main stem large rivers, connected side } \\
\text { arms }\end{array}$ \\
\hline & Zingel streber & Danube streber & $\begin{array}{l}\text { Main stem small to large rivers, } \\
\text { connected sider arms }\end{array}$ \\
\hline \multirow[t]{2}{*}{ Amphibian } & Bombina sp. & $\begin{array}{l}\text { Fire-bellied } \\
\text { toads }\end{array}$ & Fish free seasonal ponds \\
\hline & Triturus dobrogicus & $\begin{array}{l}\text { Danube crested } \\
\text { newt }\end{array}$ & Temporary water bodies \\
\hline \multirow[t]{2}{*}{ Bird } & Haliaeetus albicilla & $\begin{array}{l}\text { White tailed } \\
\text { eagle }\end{array}$ & Undisturbed wetlands \\
\hline & Alcedo atthis & $\begin{array}{l}\text { Common } \\
\text { kingfisher }\end{array}$ & Active erosion and natural substrate \\
\hline Mammal & Lutra lutra & Otter & Overall natural habitat conditions \\
\hline
\end{tabular}


Spatial mapping of ESS was conducted using the ARIES pollination, recreation and flood models submodels.

A spatial database combining the ARIES outputs with the outputs of the probabilistic species modelling was interrogated using clustering to identify multifunctional river and flood plain reaches supporting biodiversity and ESS supply. These multi-functional clusters were then mapped.

The model used a multi-objective optimization tool (e.g. Sacchelli et al. 2013), which enabled systematic optimization for different management objectives. One objective was to prioritize sections for conservation or restoration with a high remaining multi-functionality to reduce effort and costs, a second objective was to prefer sites with high reversibility (i.e. low level of human use) to increase probability of success, and finally to prefer semi-natural areas to reduce costs and loss of agricultural yield. Different weightings of the three objectives represent different possible management plans and therefore can be used as a basis for a more integrated and targeted planning. This process resulted in the development of a suite of potential target areas for restoration, conservation or mitigation efforts.

Consistent with other studies (Egoh et al. 2011; Maes et al. 2012), Funk et al. (2019) recorded a high overlap between areas important for biodiversity and areas important for ESS supply, pointing to a close interrelationship between biodiversity and ESS that is often greater in natural systems (Chan et al. 2011; Schneiders et al. 2012). Specifically, the multi-functionality approach tested by Funk et al. (2019) showed that in the study area, only natural and near-natural river-floodplain systems provided habitat for various aquatic species as well as multiple ESS.

In the study, sites with greater probability of restoration success, indicated by low level of driver intensity related to navigation, hydropower and flood protection constraints as well as sites with high level of remaining semi-natural area (compared to agricultural area) were prioritized. In this way the study addressed potential opportunity costs of restoration efforts across the entire Danube River. This approach afforded the ability to provide better cost-effectiveness in achieving large scale conservation and ESS targets at the catchment scale (Bladt et al. 2009; Egoh et al. 2014), and to potentially avoid conflicts with drivers.

\section{EBM Principles}

Overall the application of the LF to the Danube Basin, illustrated the complexity of interactions between human activities, ecosystem components and the ESS they provide, and is useful in identifying the most important ecosystem components with respect to ESS supply as well as the types of activities that most likely affect these components through pressures. With respect to the EBM principles, the LF can support the first principle in terms of communicating the links between ecological integrity, biodiversity (expressed at the habitat level) and ESS. The LF is not spatially explicit and can be transferred and adapted for use at in any similar system and applied to any spatial scale of interest thereby supporting the second principle 
(appropriate spatial scales) of EBM. The LFs are developed by 'experts' on a given location, who assess the activities and pressures, based on their knowledge. While LFs require an holistic view of a system, they do not necessarily integrate insights from a range of disciplines (principle 3) rather they characterize a suite of socialecological interactions (principle 4). In its capacity to foster an understanding of the complexity of these links to promote understanding of policy synergies, they may also be used to facilitate and support policy coordination (principle 5). However, because the LF is a semi-quantitative and expert judgement based approach it is unlikely to carry sufficient confidence to justify any particular policy decision. Since the LF does not identify particular management options its current role in adaptive management (principle 6) is limited. Nevertheless, with its basis in the causal chain analysis of the DPSIR (see Elliott this volume) the linkages could potentially be extended to incorporate response options. For fully detailed accounts of development and analysis of the LF and comparison across regions, and aquatic ecosystem types, the reader is directed to Borgwardt et al. 2019, Teixeira et al. 2019, for a general description and discussion of the approach see Robinson and Culhane (2020).

The two integrated modelling studies (Domisch et al. 2019; Funk et al. 2019) exemplify how different holistic approaches can be used to identify management options which consider ecological integrity biodiversity resilience and ESS (Principle 1). Both implementations of the quantitative model coupling framework for EBM (Langhans et al. 2019), confirms how biodiversity and ESS estimates can be jointly simulated within the DRB given the availability of requisite data and models. It demonstrates that the method is very flexible and the criteria and models used are broadly applicable and the approach is transferable to other aquatic systems (Funk et al. 2019, Domisch et al. 2019).

Both approaches were spatially explicit and developed specifically to work at the appropriate spatial scales (principle 2). In the first study (Domisch et al. 2019) this included the entire catchment while the second study (Funk et al. 2019) had a more restricted focus specifically on rivers and the flood plain, nevertheless both studies worked across international borders which is a prerequisite for the work in the Danube.

Both model used a range of data sources, in particular Domisch et al. (2019) used truly multi-disciplinary, economic and environmental data (principle 3) to account for economic disparity, within the social part of the social-ecological system. This approach accounts for countries having limited financial resources (i.e. a proxy for social equity in the EBM approach) and land area in the Danube River Basin as those might face additional challenges in financing EBM in the basin.

In contrast, Funk et al. (2019) selected a method indirectly accounting for costs independent from country level's financial limitations, prioritizing sites with greater probability of restoration success at lower cost (i.e. indicated as lower loss of agricultural area). Therefore the multi-functionality approach accounts for the emerging view that ecological restoration requires restoring ecosystems for the sustainable and simultaneously provisioning of multiple goods and services such 
as water, flood protection, recreation, and biodiversity, among others to increase cost-effectiveness (Paschke et al. 2019).

One potential pitfall with both approaches is the stakeholder participation and transparency (Principle 4). Neither study directly used stakeholder input to inform the model building process, rather, the choices were made at the technical level by the modelling teams. To make the approach operational, participatory processes involving stakeholders across the catchment, member state and local levels would be a further important step. BBNs in particular are one promising technique which can be easily adapted to incorporate stakeholder input. It is possible to construct BBNs models based on stakeholder perceptions allowing co-design of modelling activities (see O'Higgins et al. 2020 for an example). In addition, the use of the AI approach included in the ARIES model may lack the transparency of more traditional deterministic environmental models, which may reduce the acceptability of model results. Elsewhere in this volume Fulford et al. 2020 discuss practical trade-offs inherent in model complexity.

Both the policy coordination potential (principle 5) and the adaptive management aspects (principle 6) are strong in both studies described above. Outputs from both models produced a suite of policy-relevant options enabling joint efforts to conserve the Danube.

Funk et al. 2019 accounted for this principle by using data and knowledge derived and used in the framework of different policies, directives and initiatives e.g. navigation and hydropower sector (e.g. TEN-T regulation), water management sector (Water Framework Directive), local data from protected areas (Birds and Habitats Directive) and spatial land use information. This includes a continuous hydro-morphological assessment for the navigable Danube River compliant with CEN standards (Schwarz 2014; ICPDR 2015), Land cover/Land use (developed to support e.g. EU Biodiversity Strategy to 2020) or sectoral data collected on the status of the waterway, critical locations for navigation and navigation class (Fairway 2016). Cause-effect relations within the network of interactions between driver, pressure and state variables along the Driver-Pressure-State chain were then analysed within a quantitative Bayesian Network approach. Therefore, the approach selected by Funk et al. 2019 provides the first large scale statistical proof of multiple relationships of biodiversity and human uses and pressures along the navigable stretch of the Danube River. Therefore, it has the potential to increase knowledge on the socio-ecological system across sectors and policies and is serving as a basis for a strategic and more integrated management approach.

The Domisch et al. (2019) study explicitly included consideration of regional inequalities and economic capacity and generated a more in-depth picture of the feasibility of particular conservation efforts, thus enabling the adaptation of plans to meet these real-world social constraints. 


\section{Conclusions}

We developed and tested different qualitative and quantitative implementations of an EBM approach for a complex socio-ecological system, the DRB. The LF approach helped to understand the complex interaction within the social-ecological system and to describe the main human activities and pressures affecting the aquatic ecosystem components. The modelling approaches summarized in this paper have increased the consideration of ecological integrity and biodiversity, accounting for multiple species and different relevant ESS. These studies illustrate approaches considering cumulative impacts by multiple human activities including land use, navigation and hydropower and integrate this multidisciplinary data and knowledge. The prioritization approaches taken fosters integrated management planning across multiple policies by creating the opportunity to pursue different policy objectives simultaneously.

All three selected EBM application for the DRB were implemented at the ecosystem scale i.e. including the whole catchment or river independent of jurisdictional, administrative or political boundaries (Borgwardt et al. 2019, Domisch et al. 2019, Funk et al. 2019) and therefore have the potential to foster transboundary cooperation for a EBM of the DRB.

Both implementations of the quantitative model coupling framework for EBM (Langhans et al. 2019), showed how biodiversity and ESS estimates can be jointly simulated within the Danube River Basin given the availability of requisite data and models. This demonstrates that the method is flexible, the criteria and models used are broadly applicable, and the approach is transferable to other aquatic systems (Funk et al. 2019, Domisch et al. 2019). The EBM principles used for qualitative assessment of the modelling approaches may serve as a useful generic basis for the design of further EBM studies.

\section{References}

Ball, I. R., Possingham, H. P., \& Watts, M. (2009). Marxan and relatives: Software for spatial conservation prioritisation. In Spatial conservation prioritisation: Quantitative methods and computational tools (pp. 185-195). New York: Oxford University Press.

Bladt, J., Strange, N., Abildtrup, J., Svenning, J. C., \& Skov, F. (2009). Conservation efficiency of geopolitical coordination in the EU. Journal for Nature Conservation, 17, 72-86.

Borgwardt, F., Robinson, L., Trauner, D., Teixeira, H., Nogueira, A. J., Lillebø, A. I., et al. (2019). Exploring variability in environmental impact risk from human activities across aquatic ecosystems. Science of the Total Environment, 652, 1396-1408.

Chan, K. M. A., Hoshizaki, L., \& Klinkenberg, B. (2011). Ecosystem services in conservation planning: Targeted benefits vs. co-benefits or costs? PLoS One, 6, e24378.

DANUBEPARKS. (2011). Strategy on conservation \& navigation. Retrieved from http://www. danubeparks.org/files/781_DANUBEPARKS_ConservationNavigation.pdf

Delacámara, G., O’Higgins, T., Lago, M., \& Langhans, S. (2020). Ecosystem-based management: moving from concept to practice. In T. O’Higgins, M. Lago, \& T. H. DeWitt (Eds.), Ecosystembased management, ecosystem services and aquatic biodiversity: Theory, tools and applications (pp. 39-60). Amsterdam: Springer. 
Domisch, S., Kakouei, K., Martínez-López, J., Bagstad, K. J., Magrach, A., Balbi, S., et al. (2019). Social equity shapes zone-selection: Balancing aquatic biodiversity conservation and ecosystem services delivery in the transboundary Danube River Basin. Science of the Total Environment, 656, 797-807.

EC. (1992). Council Directive 92/43/EEC of 21 May 1992 on the conservation of natural habitats and of wild fauna and flora L 206/7.

EC. (2000). Establishing a framework for community action in the field of water policy. Directive 2000/60/EC of the European Parliament and of the Council. Official Journal of European Communities, L327, 1-72.

EC. (2007). EU Directive of the European Parliament and of the European Council on the estimation and management of flood risks (2007/60/EU).

EC. (2011). 'Our Life Insurance, Our Natural Capital: An EU Biodiversity Strategy to 2020' Communication from the Commission to the European Parliament, the Council, the Economic and Social Committee and the Committee of the Regions COM(2011)244, Brussels (17 pp).

Egoh, B. N., Reyers, B., Rouget, M., \& Richardson, D. M. (2011). Identifying priority areas for ecosystem service management in South African grasslands. Journal of Environmental Economics Management, 92(6), 1642-1650.

Egoh, B. N., Paracchini, M. L., Zulian, G., Schägner, J. P., \& Bidoglio, G. (2014). Exploring restoration options for habitats, species and ecosystem services in the European Union. Journal of Applied Ecology, 51(4), 899-908.

Elliott, M., \& O'Higgins, T. G. (2020). From the DPSIR, the D(A)PSI(W)R(M) emerges... a butterfly-'protecting the natural stuff and delivering the human stuff'. In T. O'Higgins, M. Lago, \& T. H. DeWitt (Eds.), Ecosystem-based management, ecosystem services and aquatic biodiversity: Theory, tools and applications (pp. 61-86). Amsterdam: Springer.

Fairway, D. (2016). Fairway rehabilitation and maintenance master plan for the Danube and its navigable tributaries. Tributaries. Retrieved from http://www.danube-navigation.eu/uploads/ files/news/2016-05-31_FAIRway_National_action_plans_May_2016_final.pdf.

Fulford, R. S., Heymans, S. J. J., \& Wu, W. (2020). Mathematical modelling for ecosystem-based management (EBM) and ecosystem goods and services (EGS) assessment. In T. O'Higgins, M. Lago, \& T. H. DeWitt (Eds.), Ecosystem-based management ecosystem services and aquatic biodiversity: Theory, tools and applications (pp. 275-290). Amsterdam: Springer.

Funk, A., Martínez-López, J., Borgwardt, F., Trauner, D., Bagstad, K. J., Balbi, S., et al. (2019). Identification of conservation and restoration priority areas in the Danube River based on the multi-functionality of river-floodplain systems. Science of the Total Environment, 654, 763-777.

Habersack, H., Hein, T., Stanica, A., Liska, I., Mair, R., Jäger, E., et al. (2016). Challenges of river basin management: Current status of, and prospects for, the River Danube from a river engineering perspective. Science of the Total Environment, 543, 828-845.

Hein, T., Schwarz, U., Habersack, H., Nichersu, I., Preiner, S., Willby, N., \& Weigelhofer, G. (2016). Current status and restoration options for floodplains along the Danube River. Science of the Total Environment, 543, 778-790.

Hein, T., Funk, A., Pletterbauer, F., Graf, W., Zsuffa, I., Haidvogl, G., et al. (2018). Management challenges related to long-term ecological impacts, complex stressor interactions, and different assessment approaches in the Danube River Basin. River Research and Applications, 35, 500-509.

ICPDR. (2015). Joint Danube survey 3. A comprehensive analysis of Danube water quality, Vienna, p. 369.

ICPDR (2016). The Danube River Basin District management plan. ICPDR-International Commission for the Protection of the Danube River, Vienna, p. 164.

Langhans, S. D., Domisch, S., Balbi, S., Delacámara, G., Hermoso, V., Kuemmerlen, M., et al. (2019). Combining eight research areas to foster the uptake of ecosystem-based management in fresh waters. Aquatic Conservation: Marine and Freshwater Ecosystems, 29, 1161-1173. https://doi.org/10.1002/aqc.3012.

Lewis, N. S., Marois, D. E., Littles, C. J., \& Fulford, R. S. (2020). Projecting changes to coastal and estuarine ecosystem goods and services-models and tools. In T. O'Higgins, M. Lago, \& T. H. 
DeWitt (Eds.), Ecosystem-based management, ecosystem services and aquatic biodiversity: Theory, tools and applications (pp. 235-254). Amsterdam: Springer.

Maes, J., Paracchini, M. L., Zulian, G., Dunbar, M. B., \& Alkemade, R. (2012). Synergies and tradeoffs between ecosystem service supply, biodiversity, and habitat conservation status in Europe. Biological Conservation, 155, 1-12.

O’Higgins, T. G., Farmer, A. M., Daskalov, G., Knudsen, S., \& Mee, L. (2014). Achieving good environmental status in the Black Sea: Scale mismatches in environmental management. Ecology and Society 19, 54.

O’Higgins, T. G., Culhane, F., O’Dwyer, B., Robinson, L., \& Lago, M. (2020). Combining methods to establish potential management measures for invasive species Elodea nutallii in Lough Erne Northern Ireland. In T. O'Higgins, M. Lago, \& T. H. DeWitt (Eds.), Ecosystembased management, ecosystem services and aquatic biodiversity: Theory, tools and applications (pp. 445-460). Amsterdam: Springer.

Paschke, M. W., Perkins, L. B., \& Veblen, K. E. (2019). Restoration for multiple use. Restoration Ecology, 27, 701-704. https://doi.org/10.1111/rec.12949.

Robinson, L., \& Culhane, F. (2020). Linkage frameworks: An exploration tool for complex systems. In T. O'Higgins, M. Lago, \& T. H. DeWitt (Eds.), Ecosystem-based management, ecosystem services and aquatic biodiversity: Theory, tools and applications (pp. 213-234). Amsterdam: Springer.

Sacchelli, S., De Meo, I., \& Paletto, A. (2013). Bioenergy production and forest multifunctionality: A trade-off analysis using multiscale GIS model in a case study in Italy. Applied Energy, 104, $10-20$.

Schneiders, A., Van Daele, T., Van Landuyt, W., \& Van Reeth, W. (2012). Biodiversity and ecosystem services: Complementary approaches for ecosystem management? Ecological Indicators, 21, 123-133.

Schwarz, U. (2014). An extended method for continuous hydromorphological assessment applied in the joint Danube survey 3, 2013. Acta Zoologica Bulgarica, 66, 123-127.

Seliger, C., Scheikl, S., Schmutz, S., Schinegger, R., Fleck, S., Neubarth, J., et al. (2016). Hy: Con: A strategic tool for balancing hydropower development and conservation needs. River Research and Applications, 32(7), 1438-1449.

Sommerwerk, N., Bloesch, J., Paunović, M., Baumgartner, C., Venohr, M., Schneider-Jacoby, M., et al. (2010). Managing the world's most international river: The Danube River Basin. Marine and Freshwater Research, 61(7), 736-748.

Teixeira, H., Lillebø, A. I., Culhane, F., Robinson, L., Trauner, D., Borgwardt, F., et al. (2019). Linking biodiversity to ecosystem services supply: Patterns across aquatic ecosystems. Science of the Total Environment, 657, 517-534.

Villa, F., Bagstad, K. J., Voigt, B., Johnson, G. W., Portela, R., Honzák, M., \& Batker, D. (2014). A methodology for adaptable and robust ecosystem services assessment. PLoS One, 9(3), e91001.

Open Access This chapter is licensed under the terms of the Creative Commons Attribution 4.0 International License (http://creativecommons.org/licenses/by/4.0/), which permits use, sharing, adaptation, distribution and reproduction in any medium or format, as long as you give appropriate credit to the original author(s) and the source, provide a link to the Creative Commons licence and indicate if changes were made.

The images or other third party material in this chapter are included in the chapter's Creative Commons licence, unless indicated otherwise in a credit line to the material. If material is not included in the chapter's Creative Commons licence and your intended use is not permitted by statutory regulation or exceeds the permitted use, you will need to obtain permission directly from the copyright holder.

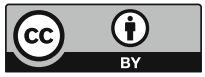

